\title{
The Importance of Geothermal Energy Resources in Turkey
}

\author{
Oyku Bilgin \\ Department of Mining Engineering, Sirnak University, Sirnak, Turkey \\ Email: ykbilgin@yahoo.com
}

How to cite this paper: Bilgin, O. (2018) The Importance of Geothermal Energy Resources in Turkey. Open Access Library Journal, 5: e4317.

https://doi.org/10.4236/oalib.1104317

Received: January 8, 2018

Accepted: February 25, 2018

Published: February 28, 2018

Copyright $\odot 2018$ by author and Open Access Library Inc.

This work is licensed under the Creative Commons Attribution International License (CC BY 4.0).

http://creativecommons.org/licenses/by/4.0/

\begin{abstract}
Turkey is located on an active tectonic zone as geological location and the country has a lot of rich in terms of geothermal energy resources. Geothermal energy which is an alternative energy resource has advantages such as low-cost, safe, natural and clean resource. Geothermal energy is defined as hot water and steam which is formed by heat that accumulated in various depths of the Earth's crust; with more than $20^{\circ} \mathrm{C}$ temperature and which contain more than fused minerals, gases and various salts than normal underground water. Geothermal energy is clearly distinguishable with its low cost, clean, safe and natural properties. Turkey has over 1300 geothermal springs that located all over the country that have various of temperatures. Generally, the western parts of Turkey have high-temperature resources for power generation. Along with power generation, it is calculated that minimum $31,500 \mathrm{MWt}$ geothermal energy can be achieved for direct heat energy use. $78 \%$ of these geothermal fields are based in Western Anatolia, 9 in Central Anatolia, nearly, 5\% in Eastern Anatolia, 7\% in the Marmara Region and 1\% in the other regions. Turkey has $90 \%$ low or medium enthalpy geothermal resources and suitable for direct applications (heating, thermal tourism, mineral waters etc.). Additionally, there are $10 \%$ for indirect applications (electric energy production). In this study, the importance of geothermal energy resources was investigated in Turkey.
\end{abstract}

\section{Subject Areas}

Environmental Sciences

\section{Keywords}

Geothermal Energy, Renewable Energy, Clean Energy, Energy Potential 


\section{Introduction}

The demand for energy in the world grows rapidly and is expected to continue to grow in the near future as a result of the social, economical and industrial developments and a high level of population growth. In parallel with this development, renewable energy sources have received increasing attention from the world due to the limited reserves of fossil fuels and their negative impacts on the environment. In this regard, the utilization of the renewable energy resources, such as solar, geothermal and wind energy appears to be one of the effective solutions [1] [2].

Despite the limitations of Planet Earth's conventional energy resources, the demand for energy is continuously rising as a result of increasing population and industrialization. The utilization of fossil energy resources is presently causing increasingly disastrous effects on the global environment. In this regard, there is urgent need to deploy sustainable and environmentally clean energy sources. An important contribution could be made by rapidly expanding the use of renewable energy sources, such as geothermal energy. The decline in fossil resource reserves, the fact that fossil resources are not infinite, and use increase the importance of renewable energy sources. Sun, wind, environmental, economic and diversification of energy production in the assessment of renewable energy sources such as geothermal potential is important in the world and Turkey [3].

Geothermal lexically means ground heat. Geothermal spring means the natural heat energy conveyed by water, vapor and gas from the reachable depths of the crust to the earth. The hot water bringing this energy to the earth is called geothermal fluid. It will be useful to explain another term frequently confused with these concepts: natural-mineral water. This hot and cold water forms at varying depths of the crust under suitable geological conditions and automatically rises to earth with high mineral content enabling it to be used for therapeutic and healing purposes. In other words, geothermal energy can be defined as hot water and vapor formed by high temperatures generated by the natural disintegration of plutonium and radioactive elements in magma with a temperature continuously higher than $20^{\circ} \mathrm{C}$ and dissolved mineral, salt and gas content bigger than normal underground and aboveground waters. It can be economically used directly or by conversion into other energy types.

Given its various advantages and the financial of our country, geothermal energy should be of first priority regarding energy needs. Geothermal energy is within the inexhaustible energy group just like hydraulic, solar and wind energy. Hence, it is considerably long-lasting compared to coal, gas, natural gas, oil shale and nuclear energy resources which are exhaustible [4].

Geothermal energy cost is $50 \%-80 \%$ lower compared to other resources both in terms of power generation and heating. And this rate is gradually increasing. Unlike fossil and nuclear-based power generation, it causes lesser and more acceptable environmental problems. National technology can be easily developed 
in geothermal energy and particularly in non-electrical applications. Western and North-Western Anatolia, where electricity deficit is typically high, have high-heat resources suitable for power generation, while Central and Eastern Anatolia cover low-heat resources for heating [5]. While there are several classifications by country, geothermal energy is mainly divided into three groups: low-temperature fields within the range of $20^{\circ} \mathrm{C}-70^{\circ} \mathrm{C}$, mid-temperature fields within the range of $70^{\circ} \mathrm{C}-150^{\circ} \mathrm{C}$, high-temperature geothermal fields over $150^{\circ} \mathrm{C}[6]$.

\section{Electricity Generation Power Plants in Turkey}

Today, at some locations around the country, geothermal energy is used to generate electricity, or geothermal heat is used directly for applications such as space heating, aquaculture, and industrial processes [7]. Turkey is located on the Alpine-Himalayan orogenic belt and the Miocene or younger grabens are developed as the result of this orogeny. Turkey is surrounded by seas on three sides: the Black Sea to the north, the Marmara Sea and Aegean Sea to the west and the Mediterranean Sea to the south. Preliminary data show that the Marmara and Aegean regions of Turkey are rich in geothermal energy, which can be used for electricity production. Turkey is a country with significant potential in geothermal energy. Resource assessments have been made many times by the General Directorate of Mineral Research and Exploitation (MTA). Turkey has a place among the world's first seven countries with respect to the abundance of its geothermal resources [8] [9] [10]. Turkey has a great geothermal potential in connection with Alpine-Himalayan orogenic belt and due to orogenic, magmatic and volcanic activities. There are over 600 hot water springs reaching up to $100^{\circ} \mathrm{C}$ with natural vapor and hydrothermal alterations in connection with grabens limited to active faults and diffuse young volcanism. Turkey has a geothermal potential of 31,500 MW. Much of this potential is concentrated in Western Anatolia (77.9\%). Only $13 \%$ of this potential (4000 MW) was made available for use by MRE (Mineral Research and Exploration Institute). 55\% of the geothermal areas in Turkey are suitable for heating applications. Geothermal energy is employed to heat 1200 decares of greenhouse and 100,000 houses in 15 settlements are heated with geothermal energy [10]. In Figure 1 are shown Turkey's some important electricity generation power plants in Turkey Aegean region [11].

Turkey has a rich geothermal energy potential due to the influence of different tectonic belts originating from Alpine-Himalayan Orogenesis and a part of this potential is used in diverse applications. The fields and their temperature values are given Figure 1 and Figure 2: Aydin-Germencik $\left(232^{\circ} \mathrm{C}\right)$, Aydın-Buharkent $\left(127^{\circ} \mathrm{C}\right)$, Denizli-Kizildere $\left(242^{\circ} \mathrm{C}\right)$, Denizli-Nazilli $\left(127^{\circ} \mathrm{C}\right)$, Canakkale-Tuzla $\left(173^{\circ} \mathrm{C}\right)$, Aydin-Salavatli $\left(171^{\circ} \mathrm{C}\right)$ Manisa-Salihli-Caferbeyli $\left(155^{\circ} \mathrm{C}\right)$, Manisa-Alaşehir (287.5) Kutahya-Simav $\left(162^{\circ} \mathrm{C}\right)$, Kutahya-Şaphane $\left(181^{\circ} \mathrm{C}\right)$, Izmir-Seferihisar $\left(153^{\circ} \mathrm{C}\right)$, İzmir-Dikili $\left(130^{\circ} \mathrm{C}\right)$, İzmir-Balçova $\left(136^{\circ} \mathrm{C}\right)$. Total 


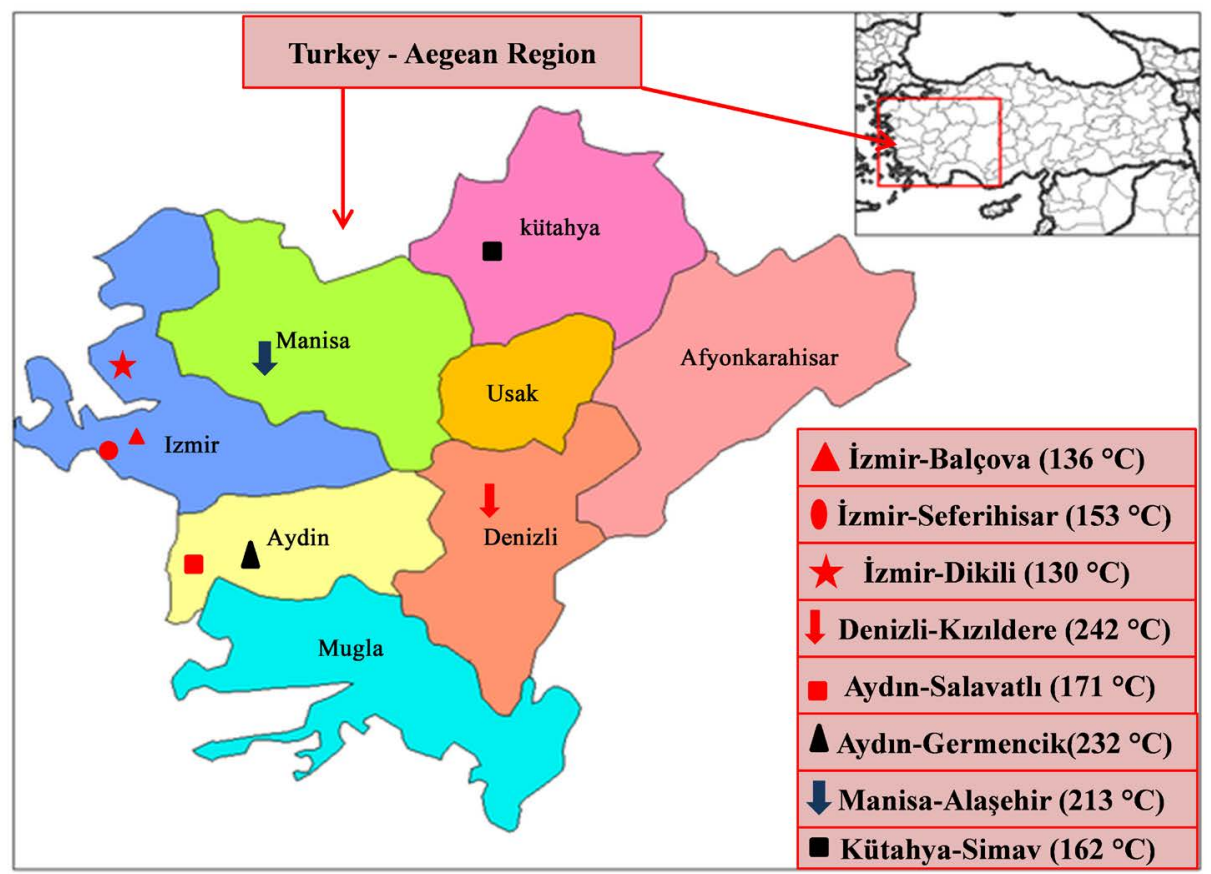

Figure 1. Electricity generation some power plants in Turkey Aegean Region [12].

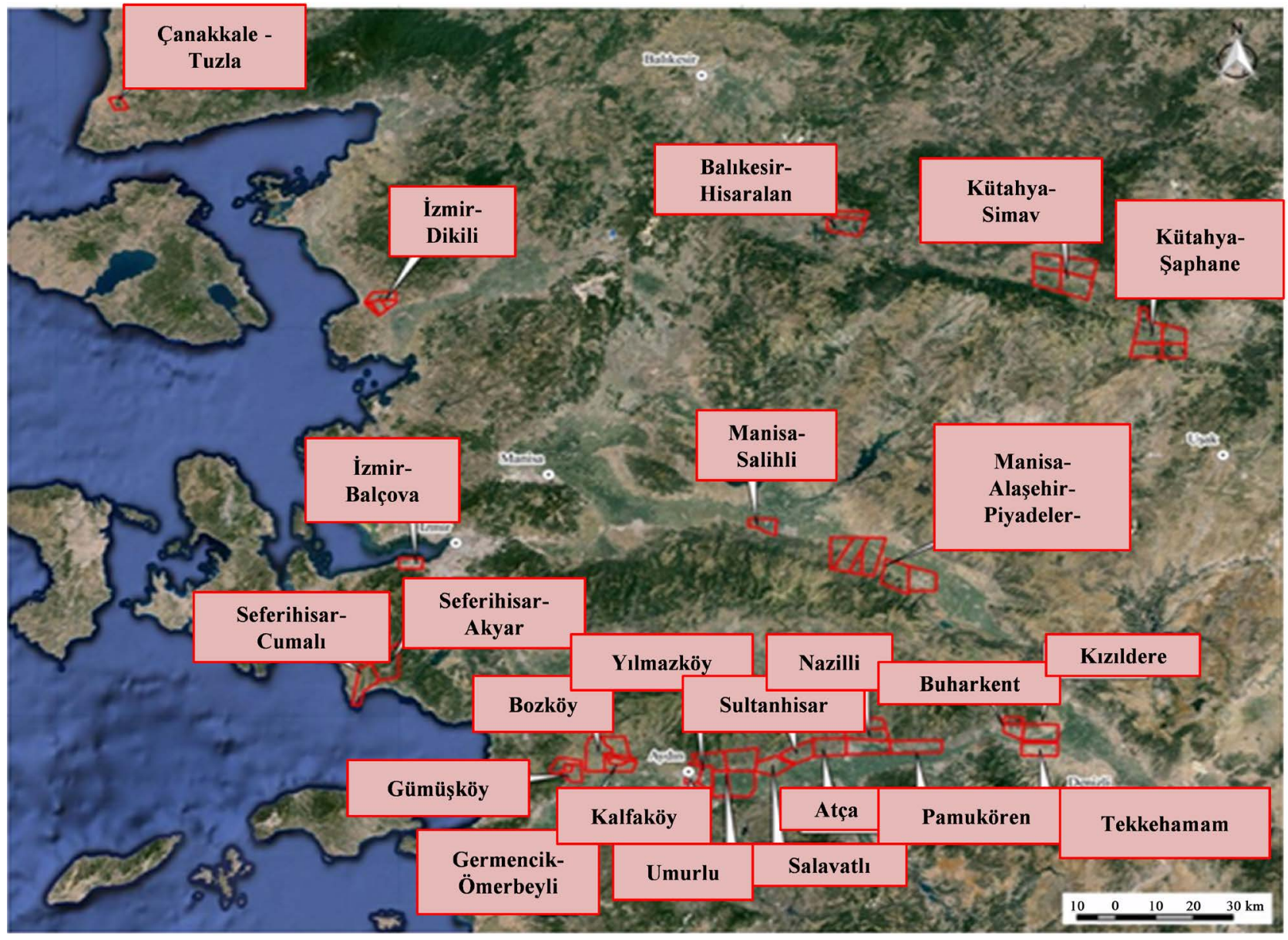

Figure 2. Turkey Aegean Region Electric fields [13]. 
number of production wells is expected to be around 400. In addition, 300 gradient drilling operations took place. Research activities of MRE in 1962 picked up speed with the discovery of Kizildere-Denizli field which enabled power generation. Ongoing research activities led to the discovery of Germencik-Aydin and Canakkale-Tuzla fields suitable for power generation. Balikesir-Gonen, Kutahya-Simav, Kirsehir, Kizilcahamam, Izmir-Balcova, Afyon-Omer, Izmir-Narlidere, Afyon-Sandikli, Kozakli ve Diyadin fields are spotted for heating purposes [10] [11].

When it is examined in Figure 1 and Figure 2, there are important electrical areas in the Aegean region. Geothermal sources have widespread uses in Turkey. Today geothermal energy is used for electricity production, heating (greenhouse and residences), thermal and health tourism, industrial mineral achievement and for drying purposes. First geothermal electricity generation held in Kizldere geothermal field by MTA in 1975 and was initiated by Kizildere power plant in Saraykoy district of Denizli with 0.5 MWe power. Geothermal areas which are suitable for direct applications (heating, thermal tourism, the output of minerals, etc.), while $10 \%$ are suitable for indirect applications (generation of electricity) [14].

\section{Important Geothermal Energy Activity in Turkey}

Department of Energy Mineral Research and Exploration continous the works which are about geothermal energy rapidly. As a result of geothermal energy exploration drilling in Manisa-Alaşehir in 2011, they reached down a depth of $2750 \mathrm{~m}$. The highest temperature geothermal shaft in Turkey was completed and the temperature of shaft bottom reached $287.5^{\circ} \mathrm{C}$. Though $44,418 \mathrm{~m}$ of drilling work was planned, $27,760.69 \mathrm{~m}$ of drilling work was carried out in 2011. In total, 244.2 MWt of thermal energy was made visible. On behalf of the MTA, drilling and investigation works in geothermal fields in Denizli, Çanakkale, Aydın, Balıkesir, İzmir, Konya, Afyon, Manisa, Eskişehir go on. Additionally, by drilling $1216 \mathrm{~m}$ in İzmir-Seferihisar-Akyar, a new energy field whose reservoir temperature was $141.18^{\circ} \mathrm{C}$ was discovered. In Figure 3 shows Search application for geothermal energy in Turkey. Turkey has 25 fields containing potentially suitable for electricity generation and all of these sites is located in western Anatolia. The installed power producing electiricity is $114.2 \mathrm{MWe}$. When all of these development in working areas are completed, this capacity can be removed to 720 MWe. The amount of the total investments which are already generating electricity, projected, and being under construction in these sites has reached to 366 MWe [15].

Geothermal energy in Turkey are used directly as central heating, greenhouse heating, and thermal tourism. Geothermal energy are utilized for central residential heating in 12 provinces (Equivalent to 88,893 residence, $800 \mathrm{MWt}$ ), greenhouses on 20 site (The equivalent of 2,488,691 $\mathrm{m}^{2}, 487 \mathrm{MWt}$ ), therapy and thermal tourism in 350 thermal plant [15]. Department of Energy Mineral 


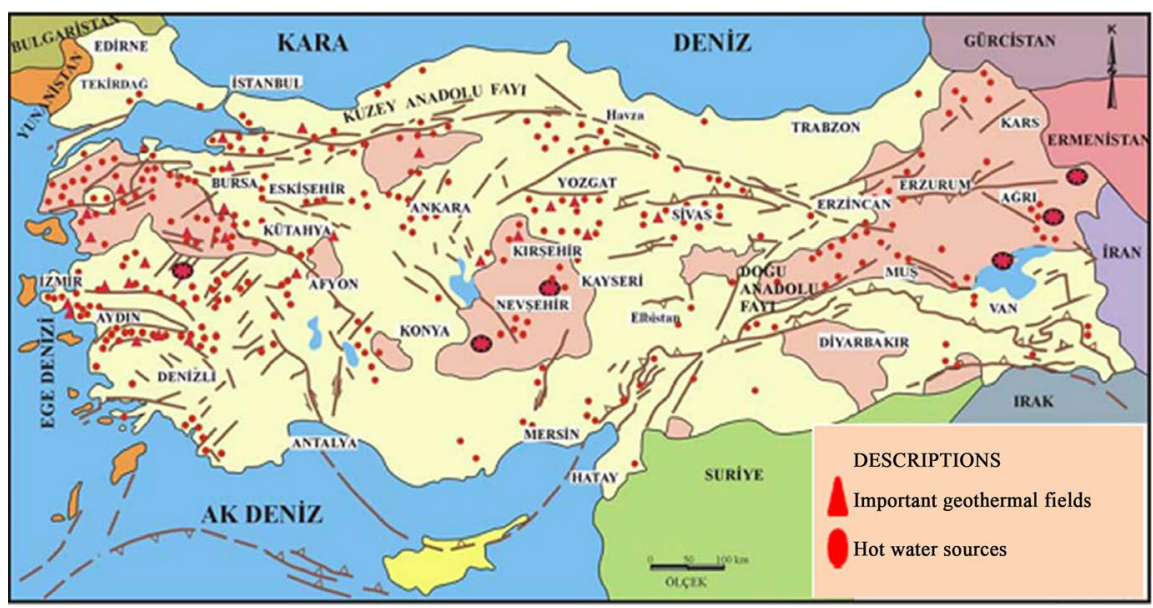

Figure 3. Search application for geothermal energy in Turkey [16].

Research and Exploration raised number of drilling machine from in total 8, 5 of which was deep drilling machine in 2010 to 9 in 2011 and has continued to operate non-stop with 3 high drilling capacity machines added machine park newly. Besides, geothermal energy exploration drilling has been carried out by the private sector in 5 several location.

\section{Development of Geothermal Energy in Turkey}

The installed capacity of geothermal energy as of year 2016 was $12.8 \mathrm{GWe}$ (with refer to IGA). Top five countries in this area are the USA, Philippines, Indonesia, Mexico and New Zealand. Total direct use of geothermal energy in the World with same reference is $70.329 \mathrm{MWt}$ as of year 2015. Top 5 countries in direct usage applications are China, USA, Sweden, Turkey and Iceland. Geothermal resource explorations had been started at 1962 by MTA and brought up to date with $287.5^{\circ} \mathrm{C}$ temperature with scientific researches that conducted also by MTA. Geothermal activities which come to a halt because of some political reasons in 1990s was accelerated in 2005. So, and drilling geothermal energy explorations reached from 2.000 metres to 28.000 metres and also geothermal budget increased about ten times for geothermal energy explorations.In 2005, with the support of our ministry, the development of existing geothermal resources initiated and began to search for new potential areas. Due for this mobilization, our usable geothermal heat capacity increased with total 223.000 meter drillings and additional 1.900 MWt heat energy increase was provided. Also, discovered geothermal fields reached to 234 fields. As a result of total of 613 drillings with total of 383.000 meters of depth carried out to this day, 5.000 MWt of heat energy was obtained including natural outflows.Enacted legislation as well as search investments have paved the way of investors. Thus, search, development and investment activities of geothermal projects have accelerated. With this development, the country's total geothermal heat capacity (visible amount of heat) reached to $15.500 \mathrm{MWt}$ [14]. 
Comparison of Geothermal applications in Turkey for the vears 2002-2017.

- Number of fields suitable for electricity production reached from 16 in 2002 to 25 in 2017.

- In 2002, while $500.000 \mathrm{~m}^{2}$ of greenhouses are heated from geothermal energy and now in 2017, $3.931 .000 \mathrm{~m}^{2}$ greenhouses heated with geothermal energy with increment of $686 \%$.

- $\quad$ Residential heating from geothermal energy in reached from $30.000 \mathrm{RE}$ in 2002 to $114.567 \mathrm{RE}$ in 2017 with increasement of $281 \%$.

- Electricity Production from geothermal energy reached from $15 \mathrm{MWe}$ in 2002 to 860 MWe in 2017 end of June with the increasement of \% 5.633.

- Geothermal heat capacity reached from 3.000 MWt in 2002 to 15.500 MWt in 2017 with increasement of \% 416 [14].

\section{Conclusions}

Geothermal energy is one of the most promising alternative energy sources. It is also environmentally advantageous energy sources which produce for less air pollution than fossil-fuel sources. They can be utilized in various forms such as electricity generation in Turkey. Geothermal energy has many advantages compared to other energy resources. Geothermal energy becomes more significant since it causes less environmental problems and is a sustainable source unlike fossil fuels which are gradually becoming exhausted. Today, geothermal energy is in many ways superior to fossil energy resources. It has a wide range of usage areas in the country as a local, renewable, cheap and eco-friendly source. Geothermal energy has the following properties: multi-purpose usage such as power generation, heating, cooling, thermal tourism, mineral-salt output, industrial use (integrated). More cost-efficient in terms of cost compared to fossil fuels and other alternative sources. Ensures comfort, clean air, cost-efficiency and healthy conditions in urban life through transition from stoves to central heating. On-site fulfilment of energy needs to enhance regional development.

As a result; Turkey has a big potential, like several areas in the world. Particularly the western parts of Turkey have high-temperature resources for power generation. Along with power generation, it is calculated that minimum 31,500 thermal MW energy can be achieved for direct heat energy use (urban heating, agricultural or industrial applications). 150,000 decares of area can be heated with this energy and 6,000,000 tons of crops could be produced which provides a great contribution to national economy.

According to investigations carried out Energy and Natural Resources in Turkey; By the end of July 2017, country electricity was generated from natural gas of $34 \%$, from coal of $31 \%$, from hydraulic power of $24 \%$, from wind of $6 \%$, from geothermal energy of $2 \%$ and from other sources of $3 \%$. As of the end of July 2017, the distribution of our installed power by resources; $33.6 \%$ of hydraulic energy, $28.1 \%$ of natural gas, $21.5 \%$ of coal, $7.7 \%$ of wind, $1.1 \%$ of geothermal and $7.4 \%$ of other [17]. When these datas are examined; although 
Turkey is a country rich in geothermal energy, should evaluate this potential by establishing new power generation plants. With new projects and researches, geothermal energy resources should be evaluated in the most efficient way.

\section{References}

[1] Hepbasli, A. and Ozgener, O. (2004) A Review on the Development of Wind Energy in Turkey. Renewable and Sustainable Energy Reviews, 8, 257-276. https://doi.org/10.1016/j.rser.2003.10.006

[2] Bilgili, M., Sahin, B. and Yasar, A. (2007) Application of Artificial Neural Networks for the Wind Speed Prediction of Target Station Using Reference Stations Data. Renewable Energy, 32, 2350-2360. https://doi.org/10.1016/j.renene.2006.12.001

[3] Küresel Enerji Politikaları ve Türkiye, TMMOB 8. Enerji Sempozyumu (2012). http://www.emo.org.tr/ekler/49895dc8cac4df4_ek.pdf

[4] Şamilgil, E. (1992) Jeotermal Enerji, Yıldız Teknik Üniversitesi, Kocaeli Mühendislik Fakültesi Jeoloji Mühendisliği Bölümü, İstanbul, 262.

[5] Başol, K. (1995) Doğal Kaynaklar Ekonomisi (Doğal Kaynaklar, Enerji ve Çevre Sorunları), Anadolu Matbaası, 5.

[6] Arslan, S., Darıcı, M. and Karahan, Ç. (2018) Türkiyenin Jeotermal enerji potansiyeli. http://www1.mmo.org.tr/resimler/dosya_ekler/a0819e9e2f84a52_ek.pdf

[7] Geothermal Technologies Program Strategic Plan (2004) Energy Efficiency and Renewable Energy. US Department of Energy, Washington DC, 1-15.

[8] Acar, H.I. (2003) A Review of Geothermal Energy in Turkey. Energy Sources, 24, 1083-1088. https://doi.org/10.1080/00908310390233603

[9] Kose, R. (2005) Research on the Generation of Electricity from the Geothermal Resources in Simav Region, Turkey. Renewable Energy, 30, 67-79. https://doi.org/10.1016/j.renene.2004.04.004

[10] Demirbas, A. (2002) Turkey's Geothermal Energy Potential. Energy Sources, 24, 1107-1115. https://doi.org/10.1080/00908310290087030

[11] Turkey's Electricity Transmission, TEİAS General Department (2011). http://www.teias.gov.tr

[12] The Aegean Region of Turkey (2018). http://www.transanatolie.com/english/turkey/aegean.htm

[13] General Directorate of Mineral Research and Exploration (2018). http://www.mta.gov.tr/v3.0/hizmetler/jeotermal-harita

[14] Republic of Turkey Ministry of Energy and Natural Resources (2017). http://www.enerji.gov.tr/tr-TR/Sayfalar/Jeotermal

[15] Department of Energy Raw Materials Research and Exploration (2011) Activity Report for the Year 2011. Ankara, 37-43.

[16] Türkiye'de Bulunan En Büyük Hazine (2018). https://jeolojimuhendisleri.net/turkiyede-bulunan-en-buyuk-hazine

[17] Republic of Turkey Ministry of Energy and Natural Resources (2018). http://www.enerji.gov.tr/en-TR/Pages/Electrical 